\title{
Potency of Sansevieria masoniana Extract against Antimicrobial Resistant Bacteria Isolated from Faeces of Pet - Reptile
}

\author{
Ady Kurnianto $^{1}$, Puspitasari ${ }^{2}$, Leni Yuroh Widyaningrum ${ }^{2}$, Irkham Widiyono ${ }^{3}$ and Yos Adi Prakoso ${ }^{1}$ * \\ ${ }^{I}$ Faculty of Veterinary Medicine, University of Wijaya Kusuma Surabaya, 60225, East Java, Indonesia \\ ${ }^{2}$ Faculty of Health, University of Muhammadiyah Sidoarjo, 61271, East Java, Indonesia \\ ${ }^{3}$ Faculty of Veterinary Medicine, University of Gadjah Mada, 55281, Yogyakarta, Indonesia \\ *Corresponding author`s Email: yos.vet.docter@gmail.com; ORCID: 0000-0003-4908-6661
}

\begin{abstract}
Reptile plays an essential role in human life and act as a reservoir of pathogenic bacteria. It became necessary because of some bacteria resistant against several antibiotics. This study aimed to evaluate the potency of Sansevieria masoniana (SM) leaf extract against isolated bacteria from the faeces of pet-reptile. A total of 129 fresh faecal samples were collected from the reptile communities in Surabaya on February 2018 until January 2019. The faeces obtained from 72 snakes, 43 lizards and 14 tortoises. The isolation was conducted using the Micro ID system. All the isolated bacteria were tested against several antibiotics using disc diffusion method, and SM extract using minimum inhibitory concentration test. The isolated bacteria were Aeromonas hydrophila (44.96\%), Bacillus $s p$ (32.55\%), Enterobacter cloacae (40.31\%), Enterococcus sp (82.17\%), Escherichia coli (96.89\%), Proteus sp (76.74\%), Pseudomonas sp (48.83\%), Salmonella enteritidis (55.03\%), and Salmonella enterica arizonae (53.48\%). Those isolated bacteria indicated various resistance patterns against several commercial antibiotics. The minimum concentration of SM extracts that potential to inhibit the colonisation of both resistant and susceptible isolated bacteria was $62.5 \mathrm{mg} / \mathrm{mL}$. This study proved that SM extract potential to inhibit the colonisation of the isolated bacteria from faeces of pet-reptile, even though, several of those isolates resistant against several commercial antibiotics.
\end{abstract}

Key words: Antibiotic, Pet - reptile, Reservoir, Resistance, Sansevieria masoniana.

\section{INTRODUCTION}

In recent years, reptile becomes one of the favourite domesticated animals in the urban area (Williams and Jackson, 2016). It indicated by the increasing number of reptile collector around the world (Pasmans et al., 2017). Reptile carriers various pathogenic bacteria that its antimicrobial resistance patterns unclearly understood. It plays an essential role in human life and its implication for public health. Reptile can act as reservoirs of Salmonella or other bacteria, and potentially pathogenic for human (Zancolli et al., 2015). Moreover, resistant bacteria have high pathogenicity and, it may increase the mortality during infection in both human and animal. Commonly, the bacteria transmits from reptile to human by direct contact (such handling) and indirect contact (ingestion of contaminated foods or consumption of reptile product) (Ebani, 2017). The best way to prevent and overcome the resistance is known by using herbal medicine, such as Sansevieria sp. Several species of Sansevieria had potential effect against degenerative and infectious disease, such Ehrlich ascites carcinoma (Haldar et al., 2010); and anti-ulcerative activity due to its saponin, flavonoid, glycoside, alkaloid, terpenoid, tannin, and anthraquinone content (Ighodaro et al., 2017). Another previous study reports the potential role of SM on the infected wound (Prakoso et al., 2018). It was necessary to elucidate the species of bacteria that potentially transmitted via the faecal-oral from pet-reptile and its resistance pattern against commercial antibiotics. Moreover, this study aimed to analyse the potency of Sansevieria masoniana (SM) against isolated bacteria from pet reptile.

\section{MATERIALS AND METHODS}

\section{Ethical approval}

Not applicable as the samples were collected from the faeces without any direct contact with the pet-reptile.

\section{Sample collection}

A total of 129 fresh faecal samples were collected from the reptile communities in Surabaya on February 2018 until January 2019. All the owners were interviewed about the sex, age, feeding and nursing of the reptile before sample collection. That data were used to compare with the results of a bacterial examination. The samples were classified into three categories that were the snake, lizard, and tortoise. Total 72-snakes faeces contanied 2 Boa constrictor (BC), 10 
Morelia viridis (MV), 3 Python molurus (PM), and 57 Python reticulatus (PR). 43-lizards included 4 Iguana iguana (II), 15 Pogona vitticeps (PV), and 24 Varanus salvator (VS). 14 tortoises faeces contanied 6 Centrochelys sulcata (CS) and 8 Geochelone elegans (GE) used in this study. All the faeces were taken with an aseptic procedure and then stored in a sterile plastic. All samples were collected and transported to the Laboratory of Bacteriology, Faculty of Health, University of Muhammadiyah Sidoarjo, East Java, Indonesia for bacterial isolation and identification.

\section{Isolation and identification}

The isolation of bacteria were conducted following the standard laboratory procedure. The isolates were reacted using Micro-ID system by utilising 15 biochemical tests and incubated at $37^{\circ} \mathrm{C}$ for 24 -hours. The biochemical test included Voges-Proskauer, nitrate broth, phenylalanine deaminase, $\mathrm{H}_{2} \mathrm{~S}$ producing, indole, decarboxylase ornithine, decarboxylase lysine, malonate, urease, esculin, Ortho-Nitro Phenyl- $\beta$-Galactoside (ONPG), arabinose, adonitol, inositol, and sorbitol. The results of the biochemical reaction were scored and recorded on data sheets. Five digits octal number was calculated and identified using Micro-ID identification manual.

\section{Sansevieria masoniana leaf extraction and phytochemical screening}

$\mathrm{SM}$ fresh leaves were obtained from the herbal store in Sidoarjo, East Java, Indonesia. It sliced and dried at $80^{\circ} \mathrm{C}$ for an hour and extracted using the $70 \%$ ethanol (Prakoso and Kurniasih, 2018). The crude extract was filtered using Whatman paper and stored at $4^{\circ} \mathrm{C}$ inside the refrigerator. Qualitative phytochemical screening was performed using standard methods against several constituents such as alkaloid, anthraquinone, flavonoid, glycoside, phenol, saponin, tannin, and terpenoid.

\section{Disc diffusion test and minimum inhibitory concentration}

The isolated bacteria were transferred into the broth media and incubated at $37^{\circ} \mathrm{C}$ until reaching the turbidity of 0.5 Mc Farland. It was inoculated on the muller hinton agar surface and waited until the inoculum infiltrates the media. Several commercial antibiotic discs (ampicillin $10 \mu \mathrm{g}$; chloramphenicol $30 \mu \mathrm{g}$; ciprofloxacin $5 \mu \mathrm{g}$; penicillin $10 \mathrm{IU}$; streptomycin $10 \mu \mathrm{g}$; and tetracycline $30 \mu \mathrm{g}$ ) and incubated at $37^{\circ} \mathrm{C}$ for 24 -hours. The inhibition zone was measured using a calliper and classified as Susceptible (S), Intermediate (I), and Resistant (R) (Adesiyun et al., 2007). Prior the Minimum Inhibitory Concentration (MIC), the extract was diluted into a stock solution using the equation below (Andrews, 2001):

Weight $(\mathrm{W})$ of extract $(\mathrm{mg})=(1000 /$ potency $(\mu \mathrm{g} / \mathrm{mL})) \times$ volume $(\mathrm{mL}) \times$ concentration of solution with multiple of $1000(\mathrm{mg} / \mathrm{L})$

The MIC was conducted by adding the $100 \mu \mathrm{L}$ extract's stock solution on the two rows of well and move $50 \mu \mathrm{L}$ to the other well until it reaches zero concentration. Following the extract, add $100 \mu \mathrm{L}$ bacterial suspension to every well that contains the stock solution, and cover using lid then incubated at $37 \mathrm{C}$ for 24 -hours. The lowest concentration that invisible the bacterial growth indicated as the potential concentration and it reported in $(\mathrm{mg} / \mathrm{mL})$.

\section{Analysis data}

The prevalence of the isolated bacteria and its resistance against commercial antibiotics were measured using the formulae below: Prevalence $(\mathrm{P})=[$ Positive Sample $(\mathrm{Ps}) /$ Total Samples $(\mathrm{TS})] \times 100$

Prevalence of the isolated bacteria and/ or its resistance against commercial antibiotics is the purpose of the prevalence word in above formulae. This study contains large variables. The relation between each variable was analysed using the multivariate analysis. It was applied to elucidate the risk factors. The potency of SM extract was analysed using the Kruskal Wallis and Man Whitney U test (SPSS, Version 16) with a probability value at level of P $<0.05$.

\section{RESULTS}

\section{Prevalence of bacteria}

Based on the isolation and identification the highest prevalence of isolated bacteria from faeces was Escherichia coli (EC) and it followed by Enterococcus sp. (ES), Proteus sp. (PTS), Salmonella enteritidis (SE), Salmonella enterica arizonae (SEA), Pseudomonas sp. (PS), Aeromonas hydrophila (AH), Enterobacter cloacae (ENC), and Bacillus sp (BS). Those result assumed that reptile was a natural reservoir for the several pathogenic bacteria such as Salmonella. It proved by the prevalence of both Salmonella (SE and SEA) in the fourth and fifth rank. EC was the highest one because it commonly found on the lower digestive system together with ENC, ES and PTS. AH was isolated from the faeces, and it suspected due to water contamination during the faecal excreted by the pet-reptile (Table 1). Another reason, it caused by food contamination. Further, a total of 685-isolates (58 of AH, 42 of BS, 52 of ENC, 106 of ES, 125 of EC, 99 of PTS, 63 of PS, 71 of SE, and 69 of SEA) collected in this study. The resistance pattern of all isolated bacteria examined against several commercial antibiotics. 
Table 1. Prevalence of isolated bacteria from faeces of pet-reptile in Surabaya, Indonesia on February 2018 until January 2019

\begin{tabular}{|c|c|c|c|c|c|c|c|c|c|c|}
\hline \multirow{2}{*}{ Pet-reptile species } & \multirow{2}{*}{$\mathbf{N}$} & \multicolumn{9}{|c|}{ Total of the positive sample } \\
\hline & & $\mathbf{A H}$ & BS & ENC & $\mathbf{E S}$ & EC & PTS & PS & SE & SEA \\
\hline $\mathrm{BC}$ & 2 & 2 & 1 & 2 & 2 & 2 & 2 & 2 & 0 & 1 \\
\hline MV & 10 & 2 & 4 & 2 & 3 & 10 & 10 & 5 & 7 & 7 \\
\hline PM & 3 & 3 & 1 & 2 & 3 & 3 & 3 & 3 & 1 & 2 \\
\hline PR & 57 & 32 & 14 & 18 & 47 & 57 & 53 & 23 & 34 & 30 \\
\hline II & 4 & 0 & 0 & 3 & 4 & 4 & 2 & 1 & 3 & 2 \\
\hline PV & 15 & 2 & 5 & 6 & 15 & 15 & 8 & 9 & 7 & 8 \\
\hline VS & 24 & 12 & 12 & 16 & 18 & 24 & 15 & 11 & 11 & 15 \\
\hline $\mathrm{CS}$ & 6 & 2 & 2 & 1 & 6 & 4 & 3 & 3 & 4 & 1 \\
\hline GE & 8 & 3 & 3 & 2 & 8 & 6 & 3 & 6 & 4 & 3 \\
\hline $\mathrm{N}$ & 129 & 58 & 42 & 52 & 106 & 125 & 99 & 63 & 71 & 69 \\
\hline $\mathrm{P}(\%)$ & 100.00 & 44.96 & 32.55 & 40.31 & 82.17 & 96.89 & 76.74 & 48.83 & 55.03 & 53.48 \\
\hline
\end{tabular}

N: Total sample, AH: Aeromonas Hydrophila, BS: Bacillus Sp, ENC: Enterobacter Cloacae, ES: Enterococcus Sp, EC: Escherichia Coli, PTS: ProTeus Sp, PS: Pseudomonas Sp SE: Salmonella Enteritidis, SEA: Salmonella Enterica Arizonae, BC: Boa Constrictor, MV: Morelia Viridis, PM: Python Molurus, PR: Python Reticulatus, II: Iguana Iguana, PV: Pogona Vitticeps, VS: Varanus Salvator, CS: Centrochelys Sulcata, GE: Geochelone Elegans.

\section{Antimicrobial susceptibility}

The isolated bacteria indicated thevaries resistance profile against tested commercial antibiotics. Mostly, the isolated bacteria exhibited high resistance profile to ampicillin, chloramphenicol, penicillin, streptomycin, and tetracycline. On the other hands, those bacteria susceptible to ciprofloxacin (6/9 species), except for PS (47.61\%) (Table 2). It suspected due to the contamination or residue on the pet-reptile feeds that was increasing the resistance of isolated bacteria.

Table 2. The resistance profile of isolated bacteria from pet reptile in Surabaya, Indonesia on February 2018 until January 2019

\begin{tabular}{|c|c|c|c|c|c|c|c|}
\hline \multirow{2}{*}{ Bacteria species } & \multirow{2}{*}{$\mathbf{N}$} & \multicolumn{6}{|c|}{ Resistant isolate (\%) } \\
\hline & & Amp & Chl & Cipr & Pnc & Strep & Tetra \\
\hline $\mathrm{AH}$ & 58 & 100.00 & 41.37 & 0 & 1.72 & 37.93 & 41.37 \\
\hline BS & 42 & 30.95 & 4.76 & 0 & 73.80 & 7.14 & 21.42 \\
\hline $\mathrm{ENC}$ & 52 & 75.00 & 57.69 & 19.23 & 61.53 & 48.07 & 28.84 \\
\hline $\mathrm{ES}$ & 106 & 1.88 & 17.92 & 18.86 & 4.71 & 0 & 0 \\
\hline $\mathrm{EC}$ & 125 & 10.40 & 4.80 & 0 & 3.20 & 7.20 & 2.40 \\
\hline PTS & 99 & 41.41 & 38.38 & 0 & 49.49 & 58.58 & 34.34 \\
\hline PS & 63 & 50.79 & 68.25 & 47.61 & 50.79 & 33.33 & 34.92 \\
\hline SE & 71 & 56.33 & 78.87 & 0 & 29.57 & 100 & 63.38 \\
\hline SEA & 69 & 55.07 & 73.91 & 0 & 0 & 81.15 & 49.27 \\
\hline
\end{tabular}

N: total sample, Amp: ampicillin, Chl: chloramphenicol, Cipr: ciprofloxacin, Pnc: penicillin, Strep: streptomycin, Tetra: tetracycline, AH: Aeromonas Hydrophila, BS: Bacillus Sp, ENC: Enterobacter loacae, ES: Enterococcus Sp, EC: Escherichia Coli, PTS: ProTeus Sp, PS: Pseudomonas Sp SE: Salmonella Enteritidis, SEA: Salmonella Enterica Arizonae.

\section{Risk factors}

This study observed several predictor factors that associated with the prevalences of the antimicrobial resistance profile of isolated bacteria. Based on the finding, there were no consistent factors that influence the antimicrobial resistance profile. Several bacteria such as AH, BS, ENC, PTS, and PS indicated that age, cleaning, and feed's type was an influence on its resistance, however, there was no potential factor to ES, EC, and SEA (Table 3). Cleaning, age and type of feed had a significant and coefficient value which respectively contained coefficient $=0.99$ for $\mathrm{AH}(\mathrm{P}=0.037)$; coefficient $=-1.486$ for PTS $(\mathrm{P}=0.019)$ and coefficient $=0.93$ for PS $(\mathrm{P}=0.044)$ based on cleaning; coefficient $=-0.602$ for $\mathrm{BS}(\mathrm{P}=0.043)$ and coefficient $=0.48$ for $\mathrm{PS}(\mathrm{P}=0.046)$ based on age and coefficient $=-0.629$ for $\mathrm{AH}(\mathrm{P}=0.033)$ and coefficient $=-0.674$ for ENC $(\mathrm{P}=0.026)$ based on type of feeds. It proved that the mentioned factors partially influence the antimicrobial resistance profile among species of present study.

\section{Qualitative phytochemical screening of SM extract}

The preliminary study proved that SM extract contains several bioactive compounds such as alkaloid, anthraquinone, flavonoid, glycoside, phenol, saponin, tannin and terpenoid. The preliminary study proved that SM extract contains several bioactive compounds such as alkaloid (+), anthraquinone (+), flavonoid (+), glycoside (+), phenol (+), saponin (+), tannin (+) and terpenoid (+).

\section{Minimum inhibitory concentration of Sansevieria masoniana extract against isolated bacteria}

The SM extracts had different potency to inhibit bacterial colonisation. It could repress $100 \%$ of the bacterial growth of AH, BS, ENC, and ES in $125 \mathrm{mg} / \mathrm{mL}$ concentration. Surprisingly, the effective potential (100\%) of the lower concentration $(65 \mathrm{mg} / \mathrm{mL})$ and high concentration $(500 \mathrm{mg} / \mathrm{mL})$ of $\mathrm{SM}$ extracts against both isolated Salmonella species 
were obtained in table 4 . Based on the statistical results, the SM extract was significantly $(\mathrm{P}<0.05)$ inhibiting all the bacterial colonisation from reptile's faeces with varying doses. The highest effective doses were $500 \mathrm{mg} / \mathrm{ml}$ and the lowest was $62.5 \mathrm{mg} / \mathrm{ml}(\mathrm{P}<0.05)$.

Table 3. Logistic regression analysis of antimicrobial resistances pattern of isolated bacteria

\begin{tabular}{lcccccc}
\hline \multirow{2}{*}{ Bacteria species } & $\mathbf{N}$ & \multicolumn{3}{c}{ Odds ratio of the predictor factors } \\
\cline { 3 - 7 } & 58 & $\begin{array}{c}\text { Pet-reptile } \\
\text { Species }\end{array}$ & Sex & Age & Cleaning & Type of feed \\
\hline AH & 42 & 0.96 & 1.84 & 1.10 & $2.69^{*}$ & $0.53^{*}$ \\
BS & 52 & 1.22 & 1.51 & $0.54^{*}$ & 0.39 & 1.00 \\
ENC & 106 & 1.27 & 0.45 & 0.75 & 1.59 & $0.51^{*}$ \\
ES & 125 & 0.89 & 0.50 & 0.70 & 1.83 & 1.72 \\
EC & 99 & 0.77 & 1.00 & 1.12 & 0.65 & 0.76 \\
PTS & 63 & 1.00 & 0.86 & $1.61^{*}$ & $0.22^{*}$ & 0.63 \\
PS & 71 & 0.91 & $3.79^{*}$ & 0.80 & $2.55^{*}$ & 1.71 \\
SE & 69 & 0.95 & 1.22 & 0.89 & 0.71 & 1.02 \\
SEA & & & 0.74 & 0.69 \\
\hline N
\end{tabular}

N: total sample, AH: Aeromonas Hydrophila, BS: Bacillus Sp, ENC: Enterobacter Cloacae, ES: Enterococcus Sp, EC: Escherichia Coli, PTS: ProTeus Sp, PS: Pseudomonas Sp SE: Salmonella Enteritidis, SEA: Salmonella Enterica Arizonae, * the different superscript on the same column showed significance value $(\mathrm{P}<0.05)$

Table 4. Minimum inhibitory concentration of Sansevieria masoniana extract ( $\mathrm{mg} / \mathrm{mL})$ against isolated bacteria

\begin{tabular}{|c|c|c|c|c|c|c|c|c|c|c|c|}
\hline \multirow{2}{*}{ Bacteria species } & \multirow{2}{*}{$\mathbf{N}$} & \multicolumn{10}{|c|}{ Percentage of susceptible isolates against several concentration of SM extract (\%) } \\
\hline & & 500 & 250 & 125 & 62.5 & 31.25 & 15.6 & 7.8 & 4 & 2 & 1 \\
\hline $\mathrm{AH}$ & 58 & $100.00 *$ & $100.00 *$ & $100.00 *$ & 44.82 & 0 & 0 & 0 & 0 & 0 & 0 \\
\hline BS & 42 & $100.00 *$ & $100.00 *$ & $100.00 *$ & $69.04 *$ & 0 & 0 & 0 & 0 & 0 & 0 \\
\hline ENC & 52 & $100.00 *$ & $100.00 *$ & $100.00 *$ & 46.15 & 0 & 0 & 0 & 0 & 0 & 0 \\
\hline ES & 106 & $100.00 *$ & $100.00 *$ & $100.00 *$ & 0 & 0 & 0 & 0 & 0 & 0 & 0 \\
\hline $\mathrm{EC}$ & 125 & $100.00 *$ & $62.40^{*}$ & 0 & 0 & 0 & 0 & 0 & 0 & 0 & 0 \\
\hline PTS & 99 & 42.42 & 0 & 0 & 0 & 0 & 0 & 0 & 0 & 0 & 0 \\
\hline PS & 63 & $100.00 *$ & $100.00 *$ & 0 & 0 & 0 & 0 & 0 & 0 & 0 & 0 \\
\hline SE & 71 & $100.00 *$ & $100.00 *$ & $100.00 *$ & $100.00^{*}$ & 0 & 0 & 0 & 0 & 0 & 0 \\
\hline SEA & 69 & $100.00 *$ & $100.00 *$ & $100.00 *$ & $100.00 *$ & $85.50 *$ & 5.79 & 0 & 0 & 0 & 0 \\
\hline
\end{tabular}

N: total sample, AH: Aeromonas Hydrophila, BS: Bacillus Sp, ENC: Enterobacter Cloacae, ES: Enterococcus Sp, EC: Escherichia Coli, PTS: Pro Teus Sp, PS: Pseudomonas Sp SE: Salmonella Enteritidis, SEA: Salmonella Enterica Arizonae, * the different superscript on the same column showed significance value $(\mathrm{P}<0.05)$,

\section{DISCUSSION}

The growing of pet-reptile owners increases the risk number of direct and indirect contact of humans with reptiles. It can promote the transmission of the pathogenic bacteria to human. Moreover, several pathogenic bacteria such as Salmonella isolated from the pet-reptile faeces proves that it potentially implicatesed for human health (Mughini-Gras et al., 2016). The previous study reported that all the excretion products of the pet-reptile harbour the pathogenic bacteria (Tomastikova et al., 2017). The high antimicrobial resistant elucidated that those bacteria increase its pathogenicity via generation of protective properties against antibiotics such as change of its membrane, produce an enzyme that inactivates the drugs, pump and neutralises the antimicrobials agents before it kills the bacteria, and decrease membrane permeability (Munita and Arias, 2016). The high resistance pattern in the isolated bacteria of pet-reptile could generate financial burden, severe infection and death.

The resistance profile that occurs in this study quite varies. From total six-commercial antibiotics, just ciprofloxacin indicatd the high susceptible pattern against isolated bacteria. It was because of ciprofloxacin is one of the semisynthetic fluoroquinolone derivates that have a broad-spectrum activity, high bioavailability and alsociprofloxacin had a DNA target (Conley et al., 2018). However, it restricted to use in animals production for the last 10-years (Jia et al., 2017). The utilisation of antibiotic in both livestock and poultry increases the risk of antibiotic's residue in food final product that potentially generates the bacterial resistant (Gouvea et al., 2015; Haag et al., 2016). It was similar to the results of present study that type of fed partially influenced on the bacterial resistant, although the other factors were not affected.

It was necessary to restrict the utilisation of synthetic antibiotic as therapy because of the high prevalence of bacterial resistant in animal and human. In recent years, the researchers observed the herbal as the antimicrobial agents, and this study utilises the SM extract (Prakoso et al., 2018). This study proved that SM potentially inhibited the bacterial colonisation in vitro. The effective concentration of the SM extract against several bacterial species was $62.5 \%$ at 125 $\mathrm{mg} / \mathrm{mL}$, even though the lower concentration $(31.25 \mathrm{mg} / \mathrm{mL})$ synergistically potential to more than $50 \%$ isolates of SEA. Similar to synthetic antibiotics, the SM extracts had various doses as an antimicrobial agent. Unfortunately, the SM 
extract indicated the low activity to depress the PTS colonisation in vitro. The SM extract had inhibited the bacterial colonisation because of its bioactive compound such as alkaloid. An alkaloid from the herbal extract potential to prevent the efflux pump system that generates the accumulation of alkaloid intracellularly and promotes the destruction of the bacterial cell (Mabhiza et al., 2016). The potential role of SM extracts increased by the anthraquinone. As the previous study reported, anthraquinone increases the aliphatic chain of the methoxy group that switch the lipophilicity of the compound and synergically upgrade its antimicrobial activity (Kemegne et al., 2017). Those mechanisms were similar to flavonoid (Wu et al., 2013), glycoside (Tagousop et al., 2018), and phenolic compound of herbal extract (RodriguezPerez et al., 2016). Saponin of the SM extract suspects played a prominent role in a proton-donating ability and can utilise as the oxidant inhibitors. Moreover, this role impairsed the membrane lipidic and cytoplasmic phase of bacteria (Akinpelu et al., 2014). Antimicrobial activity of the SM extract was supported by tannin and terpenoid. Tannin inhibits the enzyme production of bacteria (Redondo et al., 2014), and terpenoid forms a strong atomic interaction that both of those significant to destruct the bacterial cell's membrane (Daisy et al., 2008).

\section{CONCLUSION}

The prevalence of antimicrobial resistant to isolated bacteria from faeces of pet-reptile partially depends on several factors such as cleaning and type of feed. Moreover, this study proved that SM extract have potential to inhibit the colonisation of the isolated bacteria from faeces of pet-reptile, even though, several of those isolates resistant against several commercial antibiotics. Further study needs to observe the potency of SM extract against the other species of bacteria both in vitro and in vivo.

\section{DECLARATIONS}

\section{Acknowledgments}

This research was funded by Zoans Animal Save and Care, Indonesia. Technicians and students in Laboratory of Bacteriology, Faculty of Health, University of Muhammadiyah Sidoarjo and Surabaya Reptile Community were acknowledged for their assistant and providing samples.

\section{Competing interests}

The authors declared that they had no conflict of interest.

\section{Consent to publish} elsewhere.

All the authors were aware of the fact and agreed to be so named. This study did not partially or totally published

\section{Author's contribution}

AK, $\mathrm{P}$ and YAP designed the research. LYW and YAP performed the research. YAP, AK, IW wrote the manuscript. YAP checked and edited the final form of composed article.

\section{REFERENCES}

Adesiyun A, Offiah N, Seepersadsingh N, Rodrio S, Lashley V and Musai L (2007). Antimicrobial Resistance of Salmonella spp. and Escherichia coli Isolated from table Eggs. Food Control, 18: 306-311. Doi:http://dx.doi.org/10.1016\%2Fj.foodcont.2005.10.013.

Akinpelu BA, Igbeneghu OA, Awotunde AI, Iwalewa EO and Oyedapo OO (2014). Antioxidant and Antibacterial Activity of Saponin Fractions of Erythropheleum suaveolens (Guill. and Perri.) Stem Bark Extract. Scientific Research and Essays, 9: 826-833. Doi:http://dx.doi.org/10.5897/SRE2014.5844.

Andrews JM (2001). Determination of Minimum Inhibitory Concentrations. Journal of Antimicrobial Chemotherapy, 48: 5-16. Doi:https://doi.org/10.1093/jac/48.suppl_1.5.

Conley ZC, Bodine TJ, Chou A and Zechiedrich L (2018). Wicked: The Untold Story of Ciprofloxacin. PLoS Pathogens, 14, e1006805. Doi: https://dx.doi.org/10.1371/journal.ppat.1006805.

Daisy P, Mathew S, Suveena S and Rayan NA (2008). A Novel Terpenoid from Elephantopus Scaber - Antibacterial Activity on Staphylococcus aureus: a Substantiate Computational Approach. International Journal of Biomedical Science, 4: 196-203. Doi:https://www.ncbi.nlm.nih.gov/pubmed/23675090.

Ebani VV (2017). Domestic Reptiles as Source of Zoonotic Bacteria: A Mini Review. Asian Pacific Journal of Tropical Medicine, 10, 723-728. Doi: http://dx.doi.org/10.1016/j.apjtm.2017.07.020.

Gouvea R, Santos FF, Dos Aquino MHC, De Pereira VL and De A (2015). Fluoroquinolones in Industrial Poultry Production, Bacterial Resistance and Food Residues: a Review. Brazillian Journal of Poultry Science, 17: 1-10. Doi:http://dx.doi.org/10.1590/1516-635x17011-10. 
Haag G, Marin GH and Errecalde J (2016). Quantification of Residual Enrofloxacin and Ciprofloxacin in Feathers of Broiler Chickens by High-Performance Liquid Chromatography-Fluorescence after Oral Administration of the Drugs. Journal of Advanced Pharmaceutical Technology and Research, 7: 2-5. Doi: https://dx.doi.org/10.4103\%2F2231-4040.173265.

Haldar PK, Kar B, Bala A, Bhattacharya S and Mazumder UK (2010). Antitumor Activity of Sansevieria roxbughiana against Ehrlich Ascites Carcinoma in Mice. Pharmaceutical Biology, 48: 1337-1343. Doi: https://doi.org/10.3109/13880201003792592.

Ighodaro OM, Adeosun AM, Ojiko BF, Akorede AT and Williams OF (2017). Toxicity Status and Antiulcerative Potential of Sansevieria trifasciata Leaf Extract in Wistar Rats. Journal of Intercultural Ethnopharmacology, 6: 234-239. Doi:https://dx.doi.org/10.5455\%2Fjice.20170421103553.

Jia S, Zhang XX, Miao Y, Zhao Y, Ye L, Bing L and Zhang T (2017). Fate of Antibiotic Resistance Genes and Their Associations with Bacterial Community in Livestock Breeding Wastewater and Its Receiving River Water. Water Research, 124: $259-268$. Doi: https://dx.doi.org/10.1016/j.watres.2017.07.061.

Kemegne GA, Mkounga P, Ngang JJE, Kamdem, SLS and Nkengfack AE (2017). Antimicrobial Structure Activity Relationship of Five Anthraquinone of Emodine Type Isolated from Vismia laurentii. BMC Microbiology, $17: 41$. Doi:https://dx.doi.org/10.1186\%2Fs12866-017-0954-1.

Mabhiza D, Chitemerere T and Mukanganyama S (2016). Antibacterial Properties of Antibacterial Extracts from Callistemon citrinus and Vernonia adoensis against Staphylococcus aureus and Pseudomonas aeruginosa. International Journal of Medicinal Chemistry, 2016, 6304163. Doi: http://dx.doi.org/10.1155/2016/6304163.

Mughini-Gras L, Heck M and Van Pelt W (2016). Increase in Reptile-Associated Human Salmonellosis and Shift toward Adulthood in the Age Group at Risk, the Netherland, 1985 to 2014. Euro Surveillance, 21: 30324. Doi:https://dx.doi.org/10.2807\%2F15607917.ES.2016.21.34.30324.

Munita JM and Arias CA (2016). Mechanism of ntibiotic Resistance. Microbiology Spectrum, 4: 1-37. Doi:https://dx.doi.org/10.1128\%2Fmicrobiolspec.VMBF-0016-2015.

Pasmans F, Bogaerts S, Braeckman J, Cunningham AA, Hellebuyck T, Griffiths RA, Sparreboom M, Schmidt BR and Martel A (2017). Future of Keeping Pet Reptiles and Amphibians: Towards Integrating Animal Welfare, Human Health, and Environmental Sustainability. The Veterinary Record, 181: 264-264. Doi: http://dx.doi.org/10.1136/vr.104296corr1.

Prakoso YA and Kurniasih (2018). The effects of Aloe vera Cream on the Expression of CD4+ and CD8+ Lymphocytes in Skin Wound Healing. Journal of Tropical Medicine, 2018, 6218303. Doi: https://dx.doi.org/10.1155/2018/6218303.

Prakoso YA, Rini CS and Wirjaatmadja R (2018). Efficacy of Aloe vera, Ananas comosusu, and Sansevieria masoniana Cream on the Skin Wound Infected with MRSA. Advances in Pharmacological Science, 2018, 4670569. Doi:https://dx.doi.org/10.1155/2018/4670569.

Redondo LM, Chacana PA, Dominguez JE and Fernandez-Miyakawa ME (2014). Perspectives in the Use of Tannins as Alternative to Antimicrobial Growth Promoter Factors in Poultry. Frontiers in Microbiology, 5: 118. Doi:https://dx.doi.org/10.3389\%2Ffmicb.2014.00118.

Rodriguez-Perez C, Quirantes-Pine R, Uberos J, Jimenez-Sanchez C, Pena A and Segua-Carretero A (2016). Antibacterial Activity of Phenolic Compounds from Cranberry (Vaccinium macrocarpon) against Escherichia coli. Food and Function, 7 : 1564. Doi:http://dx.doi.org/10.1039/c5fo01441g.

Tagousop CN, Tamokou JDD, Ekom SE, Ngnokam D and Voutquenne-Nazabadioko L (2018). Antimicrobial Activity of Flavonoid Glycosides from Graptophyllum grandulosum and Their Mechanism of Antibacterial Action. BMC Complementary and Alternative Medicine, 18: 251. Doi: https://dx.doi.org/10.1186\%2Fs12906-018-2321-7.

Tomastikova Z, Romero SB, Knotek Z and Karpiskova R (2017). Prevalence and Characteristics of Salmonella Species Isolated from Captive Reptiles in the Czech Republic. Veterinarni Medicina, 62: 456-469. Doi:https://dx.doi.org/doi:10.17221/44/2017VETMED.

Williams DL and Jackson R (2016). Availability of Information on Reptile Health and Welfare from Stores Selling Reptiles. Open Journal of Veterinary Medicine, 6: 59-67. Doi:http://dx.doi.org/10.4236/ojvm.2016.63007.

Wu T, He M, Zang X, Zhou Y, Qui T, Pan S and Xu X (2013). A Structure-Activity Relationship Study of Flavonoida as Inhibitors of E. coli by Membrane Interaction Effect. Biochimica et Biophysica Acta (BBA) Biomembranes, 11: 2751-2756. Doi:https://dx.doi.org/10.1016/j.bbamem.2013.07.029.

Zancolli G, Mahsberg D, Sickel W and Keller A (2015). Reptiles as Reservoirs of Bacterial Infections: Real Threat or Methodological Bias?. Microbial Ecology, 70: 579-584. Doi: https://doi.org/10.1007/s00248-015-0618-3. 